\title{
Atipik granüler hücreli tümör: olgu sunumu
}

\section{Atypical granular cell tumour: case report}

\author{
๑Mehmet Zengin ${ }^{1}$, ๑Zühal Gücin ${ }^{2}$, ๑Bilgin Aksoy ${ }^{3}$, ๑Eren Acar ${ }^{4}$ \\ ${ }^{1}$ Kırıkkale Üniversitesi Patoloji Anabilim Dalı, Kırıkkale, Türkiye \\ ${ }^{2}$ Bezmi Alem Vakıf Üniversitesi Patoloji Anabilim Dalı, İstanbul, Türkiye \\ ${ }^{3}$ İstanbul Eğitim ve Araştırma Hastanesi Patoloji Anabilim Dalı, İstanbul, Türkiye \\ ${ }^{4}$ İstanbul Kent Üniversitesi Genel Cerrahi Anabilim Dalı, İstanbul, Türkiye
}

Cite this article as / Bu makaleye atıf için: Zengin M, Gücin Z, Aksoy B, Acar E. Nüks granüler hücreli tümör: olgu sunumu. J Med Palliat Care 2021; 2(2): 62-65.

\section{ÖZ}

Granüler hücreli tümör (GHT), nadir görülen mezenkimal bir neoplazmdır. Çoğunlukla baş-boyun bölgesinde özellikle de dilde yerleşim göstermekte olup nadiren rekürrens gösterir. Bu çalışmada 6 ay içerisinde nüks gösteren bir GHT olgusu sunduk. 53 yaşında erkek hasta, sırtta yavaş büyüyen kitle GHT olarak rapor edildi, tümörde pleomorfizim, mitoz, nekroz ve atipi mevcut değildi. Olgunun 6 aylık takibinde lezyon nüks etti ve tekrar eksize edildi. Nüks lezyon eskisi ile aynı özellikleri göstermekte idi ancak daha düzensiz sınırlı ve etraf dokulara infiltratif görünümde idi, ayrıca yüksek Ki- 67 oranına (\%10) sahipti. Belirsiz davranışlı kabul edilen olgumuzun 3 yıllık takiplerinde lokaluzak yayılım saptanmadı. GHT genellikle benign gidişli stromal bir tümör olmakla beraber öngörülemeyen agresiv davranma potansiyeli nedeniyle tüm olgular takip altında tutulmalıdır.

Anahtar Kelimeler: Granüler hücreli tümör, nüks, sırt

\begin{abstract}
Granular cell tumour (GHT) is a rare mesenchymal neoplasm. It is mostly located in the head and neck region, especially in the tongue, and it rarely recurs. In this study, we present a case of GHT recurring within 6 months. A slow-growing mass on the back in a 53-year-old male patient was reported as GHT, the tumour did not have pleomorphism, mitosis, necrosis or atypia. During the 6-month follow-up of the case, the lesion recurred and was excised again. The recurrent lesion had the same features as before, but with a more irregular border and infiltrative appearance to surrounding tissue, and a high Ki-67 ratio (10\%). No local-distant spread was detected in the 3-year follow-up of our case, which was considered to have uncertain behaviour. Although GHT is generally a benign stromal tumour, all cases should be followed up because of its unpredictable potential for aggressive behaviour.
\end{abstract}

Keywords: Granular cell tumour, recurrence, back

\section{Gíriş}

Granüler hücreli tümör (GHT), genellikle baş-boyun bölgesinde rastlanan nadir bir yumuşak doku tümördür. Genellikle küçük, sınırları belirsiz, tek veya multipl bir nodül şeklinde izlenmektedir (1). Lokalizasyon açısından dil ön plana çıkmakla beraber deri, solunum yolu, meme, gastrointestinal sistem gibi vücudun herhangi bir yerinde de görülebilir $(1,2)$. GHT benign bir tümördür ve Schwann hücrelerinden kaynak aldığ 1 düşünülmektedir (3). Histopatolojik olarak tümör eozinofilik-granüler sitoplazmalı poligonal hücrelerin birikiminden oluşur ve genellikle düzensiz sınırlıdır (3,4). Mitoz, nekroz, nükleer aitipi ve plemorfizm içermezler (5). Bu lezyon sıklıkla yüzey epitelinde psödoepitelyomatöz hiperplazi ile birliktelik gösterir ve iyi gözlenmezse skuamöz hücreli karsinom olarak yanlış bir yoruma yol açabilir $(6,7)$. Tedavisi tümörün tam eksizyonudur. $\mathrm{Bu}$ çalışmada, dil dışında lokalize olan ve nüks eden bir GHT olgusu tanımlıyor ve ayırıcı tanı ve progresif davranış ipuçlarını tartışıyoruz. 


\section{OLGU SUNUMU}

Elli üç yaşında erkek hasta, ilk olarak sırtında 6 aydır yavaş büyüyen kitle şikayetiyle başvurdu. $1 \mathrm{~cm}$ çapında nodüler șekilli bu kitle tanı amacıyla eksize edildi. Makroskobik olarak belirgin bir özellik göstermeyen lezyonun mikroskobik incelemesinde dermis yerleşimli, belirgin düzensiz sınırl, yer yer ince fibröz septalarla ayrılmış șeritler oluşturduğu için infiltran görünümlü lezyon izlendi. Lezyon büyük poligonal şekilli, eozinofilik-granüler sitoplazmalı, egzantrik yerleşimli küçük hiperkromatik nukeoslu ve belirgin nukleoluslu hücrelerden oluștuğu görüldü. Hücre sitoplazmalarında yuvarlak şekilli, eozinofilik-granüler görünümlü sitoplazmik birikintiler dikkati çekti (Resim 1,2). Uygulanan immünohistokimyasal çalışmada tümöral hücrelerde panCK (-), vimentin (+), S-100 (+), sitoplazmik granüller ise PAS (+) (Resim 4), diastaz (-) olarak bulundu. Cerrahi sınırlarda tümörün devam ettiği lezyon GHT olarak rapor edildi. Pleomorfizm, mitoz, nekroz ve atipi izlenmeyen vaka ön planda benign olarak değerlendirildi.

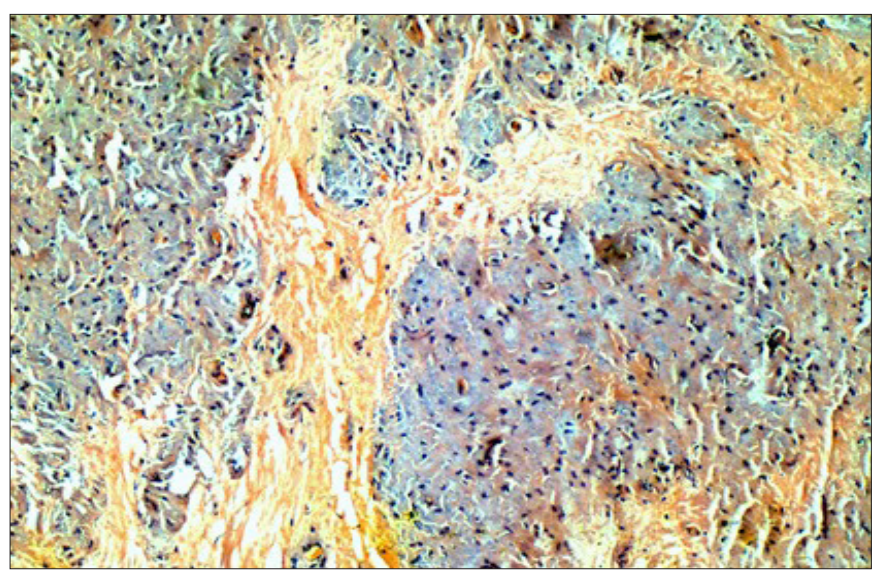

Resim 1. Granüler hücreli tümörün küçük büyütmede düzensiz sinırlı ve infiltran görünümü (x10, H\&E)

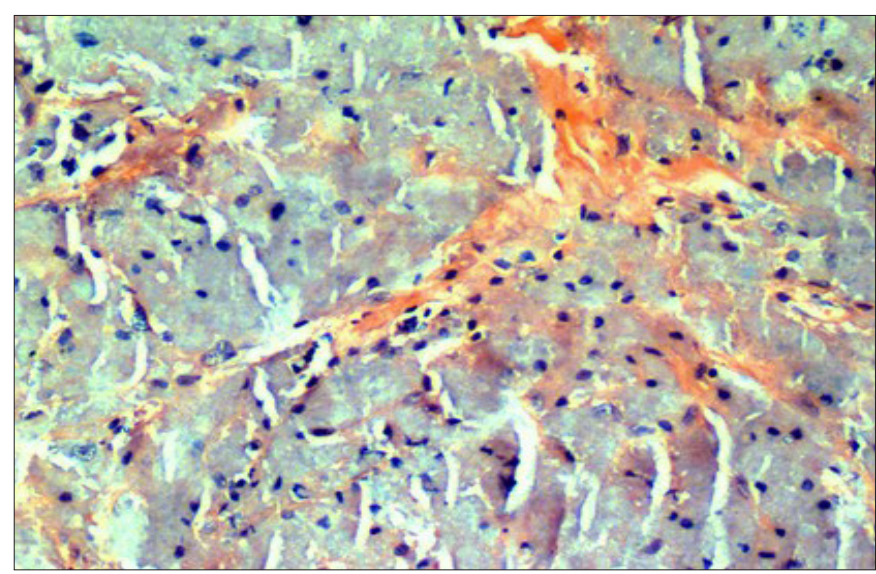

Resim 2. Granüler hücreli tümörün büyük büyütmede büyük poligonal şekilli, eozinofilik-granüler sitoplazmalı, egzantrik yerleșimli nukeoslu hücreleri (x20, H\&E)
Hastanın ilk 6 aylık takibinde lezyonun nüks ettiği görüldü ve tekrar eksize edildi. Nüks lezyonun eskisi ile aynı özelliklere sahip ancak daha düzensiz sınırlı ve etraf dokuya infiltran olduğu görüldü. Cerrahi sınırda tekrar tümör izlenen nüks GHT olarak değerlendirildi. Nüks lezyonda pleomorfizm minimal (Resim 3), mitoz, nekroz ve atipi mevcut değildi. Ki- 67 oranı ise \%10 olarak saptandı. Olgu bu haliyle atipik GHT yani davranışı belirsiz olarak kabul edildi ve takibi uygun görüldü.

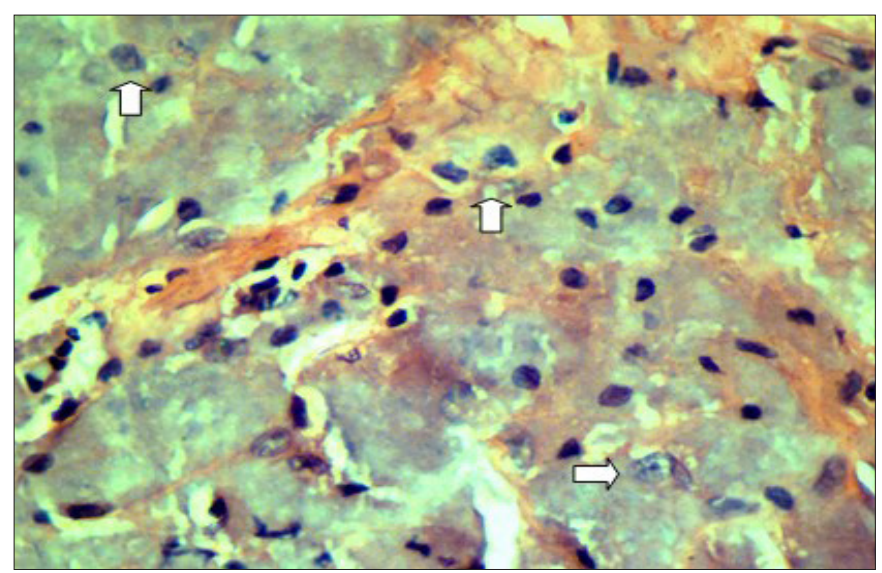

Resim 3. Nüks Granüler hücreli tümörde seyrek artmış nükleus/ sitoplazma oranına sahip büyük nukleoluslu veziküler nukleuslu hücreler (oklar) ve hafif șiddette pleomorfizm izlendi (x40, H\&E)

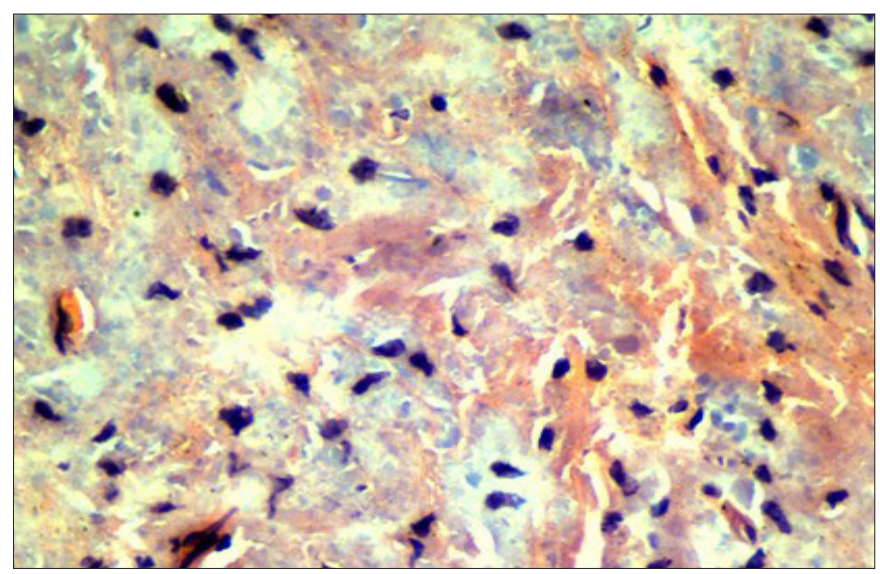

Resim 4. Granüler hücreli tümörde sitoplazmik granüllerin PAS (+) boyanması (x40, PAS)

\section{TARTIŞMA}

GHT'yi ilk olarak Abrikossoff 1926'da tanımlamıştır. Abrikossoff, tümörü mikroskopik olarak kas fibrillerine benzetmesi nedeniyle granüler hücreli miyoblastom olarak adlandırmıştır (1). GHT, vücudun herhangi bir yerinde görülebilen nadir bir mezenkimal neoplazidir. Kadınlarda iki kat daha fazla rastlanmakta olup, en sık dördüncü ve altıncı dekatlar arasında ve zencilerde görülür. Olguların yaklaşık yarısı baş-boyun bölgesinde lokalize ve bunların büyük çoğunluğu da dil sırtında ağrısız, sesil, nodüler yapı olarak karşımıza çıkmaktadır $(1,2)$. GHT’nin diğer yerleşimleri arasında dudak, ağız mukozası, maksilla, trakea, bronşlar, gastrointestinal 
sistem, meme, nörohipofiz ve göz sayılabilir (3). GHT \%30-35 oranında 2 cm'den küçük bir nodül, \%10-15 oranında multiple nodüller ve \%1-2 oranında malign olarak prezente olur (3-6). Olgumuz sirt yerleşimli olup $2 \mathrm{~cm}$ 'lik nodüler bir lezyon şeklinde prezente olmuştur.

İmmünohistokimyasal olarak GHT, S-100 protein, vimentin, myelin basic protein için pozitif, miyojenik markerlar için ise negatiftir. Hücre sitoplazmalarındaki granüller PAS (+) ve diastaz (-) boyanmaktadır (7). Histokimyasal olarak büyük oranda asid fosfataz gibi hidrolitik enzimler içeren bu granüller elektron mikroskobunda lizozom görüntüsüne sahiptir. $\mathrm{Bu}$ bulgular ve bazı GHT’nin küçük sinirlerle birlikte olması Schwann hücreleri ile ilişkisini desteklemektedir $(7,8)$. Granüler hücreler tipik olarak yüzey epiteline doğru yayılım gösterdiğinden epitelde belirgin psödoepitelyomatözhiperplaziye neden olur. Bugörünüm skuamöz hücreli karsinomla karıştırılmamalıdır $(8,9)$. Olgumuzun morfolojik görünümü literatür bilgileri ile uyumlu olup epitelde psödoepitelyomatöz görünüm izlenmemiştir.

Malign-benign GHT ayırımı genelde zordur ve malign GHT bazen sadece metaztaz ile saptanabilir. Malign GHT ilk olarak Ravich ve arkadaşları (10) tarafından tanımlanmıştır. Yapılan bir çalışmada 73 malign vakada malignite kriterleri ve prognostik faktörler araştırılmış ve altı adet histolojik kriter tayin edilmiştir. Bunlar; nekroz, iğsileşme, büyük nukleoluslu veziküler nukleus, artmış mitotik aktivite (10 büyük büyütme alanında 2'den fazla), yüksek nükleus/sitoplazma oranı ve pleomorfizmdir (11). Bu kriterlerden üç yada daha fazla kriteri taşıyan lezyonlar malign, bir yada iki kriteri taşıyanlar atipik, sadece fokal pleomorfizm olan ancak diger kriterleri taşımayanlar benign olarak sınıflandırılmıştır $(11,12)$. Histolojik bulgulara ek olarak nükleer proliferasyon belirleyicileri olan p53 ve Ki-67 oranları da malign davranış ile ilişkili bulunmuştur. Literatürde Ki-67malign olgularda \%10-50 oranında, p53 ise \%50'den fazla ornada pozitif izlenmiştir $(13,14)$. İmmünprofil için yapılan immünohistokimyasal çalışmada ise malign tümörlerin \%100'ünde vimentin (+), \%98'inde S-100 (+), \%98'inde NSE (+), \%69'unda CD57 (+) ve \%65'inde CD68 (+) boyanırken alfa düz kas antijen, desmin, EMA, sitokeratin, kromogranin ve HMB45 ile boyanma izlenmemiştir $(12,14)$. Olgumuzda malignite kriterlerinden sadece hafif pleomorfizm mevcuttu. Ancak olgunun altı ay ara ile tekrarlamış olması, Ki-67 indeksinin \%10 gibi yüksek sayılabilecek oranda saptanmas1, cerrahi sinırlarda lezyonun mevcut oluşu ve literatürde malign ve özellikle ara formda tümörler ile ilgili bilgilerin az oluşu öz önüne alındığında vaka atipik GHT olarak değerlendirilmiştir ve hasta takibinin uygun olacağı düşünülmüştür.
GHT’nin diğer iyi huylu tümörlerden ayırıcı tanısı genellikle kolay olarak yapılabilmektedir. Granüler sitoplazmanın bulunması, çapraz çizgilenme ve glikojen ihtiva etmemesi ile rabdomiyomdan, yağ damlacıklarının bulunmamas1 ile hibernoma ve fibroksantoma'dan ayrılmaktadır $(12,13)$. Tedavide en iyi yöntem geniş lokal eksizyondur. Eğer tümör hızlı büyüme gösterir veya çapı 4 cm'yi geçerse bölgesel lenf nodu disseksiyonu ve metastaz açısından radyolojik inceleme önerilmektedir. Kötü huylu olgularda kemoterapi ve radyoterapinin etkinliği henüz kanıtlanmamıştır $(13,14)$.

\section{SONUÇ}

GCT'ler yavaş büyüyen benign stromal tümörler olarak düşünülmekle beraber potansiyel olarak kötü huylu davranma özelliğine sahip olabilirler ve olgumuzda tarif edildiği gibi beklenmeyen agresiv davranışlar sergileyebilirler. Bu nedenle tüm olguların takip edilmesi gerektiğini düşünüyoruz.

\section{ETIIK BEYANLAR}

Aydınlatılmış Onam: Bu çalışmaya katılan hasta(lar) dan yazılı onam alınmıştır.

Hakem Değerlendirme Süreci: Harici çift kör hakem değerlendirmesi.

Çıkar Çatışması Durumu: Yazarlar bu çalışmada herhangi bir çıkara dayalı ilişki olmadığını beyan etmişlerdir.

Finansal Destek: Yazarlar bu çalışmada finansal destek almadıklarını beyan etmişlerdir.

Yazar Katkıları: Yazarların tümü; makalenin tasarımına, yürütülmesine, analizine katıldığını ve son sürümünü onayladıklarını beyan etmişlerdir.

\section{KAYNAKLAR}

1. Abrikossoff A. Ueber myome auseeheng von der quergestreifien willkurlich muskulatur. Virchows Arch Pathhol Anat 1926; 260: 215-33.

2. Cui Y, Tong SS, Zhang YH, et al. Granular cell tumor: A report of three cases and review of literature. Cancer Biomark 2018; 23: 173-8.

3. Moten AS, Movva S, von Mehren M, et al. Granular cell tumor experience at a comprehensive cancer center. J Surg Res 2018; 226: $1-7$.

4. Gross VL, Lynfield Y. Multiple cutaneous granular cell tumors: a case report and review of the literature. Cutis 2002; 69: 343-6.

5. Levavi H, Sabah G, Kaplan B, et al. Granular cell tumor of the vulva: six new cases Arch Gynecol Obstet 2006; 273: 246-9.

6. Machado I, Cruz J, Lavernia J, et al. Solitary, multiple, benign, atypical, or malignant: the "Granular Cell Tumor" puzzle. Virchows Arch 2016; 468: 527-38.

7. Janouskova G, Campr V, Konkolova R, et al. Multiple granular cell tumour. J Eur Acad Dermatol Venereol, 2004; 18: 347-9. 
8. Wang HX, Zhang LZ, Jin YL, et al. Female vulva granular cell tumor: report of a relapse case. Zhonghua Bing Li Xue Za Zhi 2019; 8; 48: 330-1.

9. Corso G, Di Nubila B, Ciccia A, et al. Granular cell tumor of the breast: Molecular pathology and clinical management. Breast J 2018; $24: 778-82$.

10. Ravich A, Stout AP, Ravich RA: Malignant granular cell myoblastoma involving the urinary bladder. Ann Surg 1945, 121: 361-72.

11. Miracco C, Andreassi A, Laurini L, et al. Granular cell tumour with histological signs of malignancy: report of a case and comparison with 10 benign and 4 atypical cases. Br J Dermatol 1999; 141: 573-5.

12. Pérez-González YC, Pagura L, Llamas-Velasco $\mathrm{M}$, et al. Primary cutaneous malignant granular cell tumor: an immunohistochemical study and review of the literature. Am J Dermatopathol 2015; 37: 334-40.

13. Akahane K, Kato K, Ogiso S, et al. Malignant granular cell tumor of the breast: case report and literature review. Breast Cancer 2015; 22: 317-23.

14. Fanburg-Smith JC, Meis-Kindblom JM, Fante R, et al. Malignant granular cell tumor of soft tissue: diagnostic criteria and clinicopathologic correlation. Am J Surg Pathol 1998; 22: 779-94. 